\title{
Manganese-Catalyzed Enantioselective Alkene Epoxidation
}

Metal-Catalyzed Asymmetric

Synthesis and

Stereoselective

Reactions

\section{Key words}

epoxidation

manganese

hydrogen peroxide

\section{Overall transformation:}

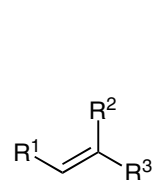

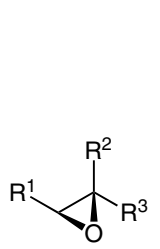

$0.42 \mathrm{mmol}$ scale

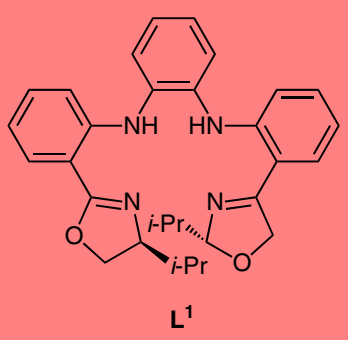

Selected examples:<smiles>CC1(C)CC(=O)c2cc(P)ccc2O1</smiles>

$\mathrm{R}=\mathrm{CN}$

$\mathrm{Cl}$

$\mathrm{NO}_{2}$

$\mathrm{CO}_{2} \mathrm{Me}$

$\mathrm{Ph}$

$\mathrm{CH}_{2} \mathrm{OH}$
95\% yield, $95 \%$ ee $93 \%$ yield, $96 \%$ ee $90 \%$ yield, $96 \%$ ee $93 \%$ yield, $94 \%$ ee $95 \%$ yield, $96 \%$ ee $98 \%$ yield, $94 \%$ ee $96 \%$ yield, $>99 \%$ ee<smiles>[R]c1ccc2c(c1)[C@@H]1O[C@H]1C1(CCCCC1)O2</smiles><smiles>c1ccc2c(c1)C[C@@H]1O[C@H]21</smiles><smiles>c1ccc2c(c1)CC[C@@H]1O[C@H]21</smiles>

$93 \%$ yield, $84 \%$ ee $\quad 99 \%$ yield, $96 \%$ ee

$\mathrm{R}=\mathrm{CN}$ $\mathrm{Br}$

$98 \%$ yield, $90 \%$ ee $91 \%$ yield, $94 \%$ ee $92 \%$ yield, $92 \%$ ee $\begin{array}{ll}\mathrm{CO}_{2} \mathrm{Me} & 97 \% \text { yield, } 90 \% \text { ee } \\ \mathrm{Ph} & 99 \% \text { yield, } 96 \% \text { ee } \\ \mathrm{NHAc} & 99 \% \text { yield, } 98 \% \text { ee }\end{array}$ $\begin{array}{ll}\mathrm{CO}_{2} \mathrm{Me} & 97 \% \text { yield, } 90 \% \text { ee } \\ \mathrm{Ph} & 99 \% \text { yield, } 96 \% \text { ee } \\ \mathrm{NHAc} & 99 \% \text { yield, } 98 \% \text { ee }\end{array}$ $\mathrm{NHAC}$<smiles>[R]C1O[C@@H]1c1ccccc1</smiles>
$\mathrm{R}=\mathrm{H} \quad 98 \%$ yield, $47 \%$ ee
$\mathrm{R}=\mathrm{Ph} \quad 95 \%$ yield, $92 \%$ ee

Gram-scale synthesis of the chiral drug (S)-levcromakalim:
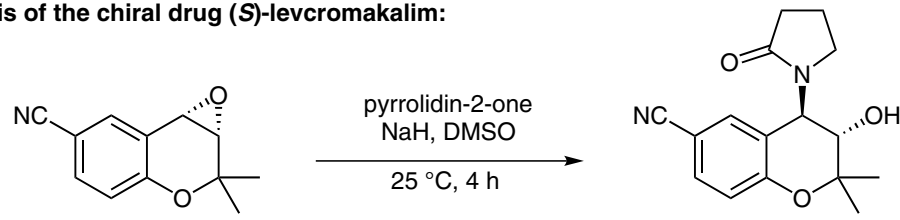

$61 \%$ yield, $97 \%$ ee

Significance: Epoxides are an important class of molecules and serve frequently as intermediates in complex molecule synthesis. Many highly effective protocols have been developed for the generation of enantioenriched epoxides by way of transition-metal and organocatalysis. However, not all classes of substrates proceed smoothly with high levels of enantioselectivity under the published methods, and therefore the development of new and robust epoxidation methods is of great interest.
Comment: Gao and co-workers report the use of Jacobsen-type manganese-catalyzed epoxidation of chromenes, indenes, styrenes, and dihydronapthalenes using a porphyrin-inspired tetradentate ligand. Products are obtained in excellent yields and enantioselectivities using a low catalyst loading (0.2 mol\%). This environmentally friendly method makes use of two equivalents of $\mathrm{H}_{2} \mathrm{O}_{2}$ as the terminal oxidant. The authors were able to extend their methodology to the synthesis of the chiral drug (S)-levcromakalim. 